\title{
PENGENDALIAN PERILAKU, DAN PENGENDALIAN INDIVIDUAL TERHADAP KINERJA AUDITOR INTERNAL PADA PT. BANK SULSELBAR CABANG SYARIAH MAKASSAR
}

\author{
Nurfaidah \\ Dosen Sekolah Tinggi Ilmu Ekonomi \\ Yayasan Pendidikan Ujung Pandang \\ Jl.Andi Tonro No.17 Makassar \\ e-mail :faidahnurfaidah48@yahoo.com
}

\section{Keywords: \\ Behavioral Control, Individual Control, and Internal Auditor Performance}

\author{
Kata Kunci: \\ Pengendalian \\ Perilaku, \\ Pengendalian \\ Individual, Kinerja \\ Auditor Internal.
}

\begin{abstract}
This study aims to analyze the effect of behavior control, and individual control on the performance of internal auditors at PT. Bank Sulselbar Makassar Sharia Branch. This research is a kind of quantitative research. The sample uses purposive sampling method by directly selecting all employees / employees as much as 35 people. Data collection methods used are Questionnaire, and documentation. Data were analyzed by multiple linear regression and bypothesis test by using t-test and F test with SPSS 23.0 for windows software. The results showed that: (1) Partial behavioral control significant effect on the performance of internal auditors. (2) Individual control partially significant effect to internal auditor performance. (3) Behavioral control, and individual controls jointly affect the performance of internal auditors at PT. Bank Sulselbar Makassar Sharia Branch.
\end{abstract}

ABSTRACT

\begin{tabular}{l}
\hline ABSTRAK \\
\hline Penelitian ini bertujuan untuk menganalisis pengaruh pengendalian \\
perilaku, dan pengendalian individual terhadap kinerjaa uditor \\
internal pada PT. Bank Sulselbar Cabang Syariah Makassar. \\
Penelitian ini merupakan jenis penelitian kuantitatif. \\
Sampel menggunakan metode purposive sampling yaitu dengan \\
memilih langsung semua pegawai/karyawan sebanyak 35 orang. \\
Metode pengumpulan data yang digunakan adalah Kuesioner, dan \\
dokumentasi. Data dianalisis dengan regresi linear berganda dan uji \\
hipotesis dengan menggunakan uji-t dan uji F dengan bantuan \\
software SPSS 23.0 for windows. Hasil penelitian menunjukkan \\
bahwa: (1) Pengendalian perilaku secara parsial berpengaruh \\
signifikan terhadap kinerja auditor internal. (2) Pengendalian \\
individual secara parsial berpengaruh signifikan terhadap kinerja \\
auditor internal. (3) Pengendalian perilaku, dan pengendalian \\
individual secara simultan mempengaruhi kinerja auditor internal \\
pada PT. Bank Sulselbar Cabang Syariah Makassar.
\end{tabular}

\section{PENDAHULUAN}

Aktivitas akuntansi mengalami perkembangan yang pesat seiring dengan kebutuhan dunia kerja khususnya yang berkaitan dengan pemeriksaan keuangan pada berbagai perusahaan dan industri perbankan yang membutuhkan tenaga auditor untuk melakukan penilaian dan pemeriksaan. Profesi akuntan publik merupakan suatu pekerjaan yang berlandaskan pada pengetahuan yang kompleks dan hanya dapat dilakukan oleh individu dengan kemampuan dan latar belakang pendidikan tertentu.

Permasalahan yang sering terjadi seperti pada industri perbankan, bahwa kinerja auditor dinilai rendah berdasarkan pencapaian hasil kerja menurut tingkat kapasitas, kemauan, 
Nurfaidah. Pengendalian Perilaku, dan Pengendalian Individual ...

dan peluang yang diberikan dalam menentukan efektivitas kerja oganisasi perbankan. Akibat kinerja manajerial yang rendah menjadikan hasil kerja yang dicapai kurang terencana, terkelola, terarah, terorganisir, dan terawasi dalam memberikan pelayanan perbankan.

Teori profesionalisme kerja auditor yang dikemukakan oleh Nugroho (2006:17), menjelaskan bahwa:

"Profesionalisme kerja adalah aktualisasi kerja profesi yang berpengalaman, otonomi, berperilaku, dan kendali personal dalam melakukan audit kerja. Ini berarti seorang auditor dalam bekerja harus mampu menjalankan prinsip profesionalisme kerja. Semakin professional seorang auditor, maka semakin terlihat pencapaian kinerja manajerial yang dihasilkan."

Seorang auditor dalam menjalankan profesinya sebagai penyedia informasi yang berguna bagi publik untuk pengambilan keputusan ekonomi yang brkaitan dengan pelaporan keuangan perbankan. Umumnya profesiona seperti auditor dalam melaksanakan aktivitasnya disebut sebagai pihak pertama, bekerja untuk kepentingan klien yang merupakan pihak kedua (pemohon jasa). Profesi auditor bukan hanya dituntut untuk melayani klien (pihak kedua) tetapi lebih mengutamakan tanggung jawab kepada masyarakat (pihak ketiga). Oleh sebab itu, akuntan publik diharapkan mampu menjalankan tanggung jawab yang ada dlam profesinya.

Auditor harus bersifat independen dan berkomitmen secara ekspisit melayani kepentingan public. Permintaan terhadap jasa audit, pajak, dan manajemen oleh berbagai organisasi baik lokal maupun multinasional, merupakan tanggung jawab utama para akuntan professional. Auditor harus berupaya untuk meningkatkan pretasi kerja dalam menjalankan profesinya. Tercapainya prestasi kerja yang baik tidak terlepas dari kualirtas sumber daya manusia yang baik pula. Prestasi kerja yang baik dapat dicapai saat 1) tujuan yang diinginkan telah dicapai 2) moderator (kemampuan, komitmen, motivasi) telah tersedia dan 3) mediator (petunjuk, usaha, ketekunan, dan strategi) telah dijalankan (Nugroho, 2006:73).

Penelitian mengenai peningkatan kinerja manajerial telah menarik perhatian banyak peneliti dan menjadi bidang yang selektif. Bebeapa variable yang mencerminkan keadaan lingkungan kerja professional, seperti: pengendalian perilaku dan pengendalian individual terhadap kinerja manajerial. Akan tetapi, masih sedikit peneliti yang mengintegrasikan variablevariabel tersebut dalam melihat pengaruhnya secara langsung dalam prakteknya sesuia dinamika organisasi yang terjadi pada industri perbankan. Hal tersebut menunjukkan bahwa kinerja auditor internal pada PT. Bank Sulselbar Cabang Syariah Makassar dikategorikan sangat bagus. Perlu dicermati adalah pengendalian auditor internal berdasarkan perilaku dan individual.Kemampuan yang dimiliki oleh auditor dalam menjalankan tugasnya, masih sering dihadapkan oleh keterbatasan dalam mengembangkan metode kerja yang efisien dan efektif, masih sering tidak melakukan penjadwalan waktu kerja yang tepat dan penentuan kriteria yang ditetapkan biasa tidak sesuai dengan standar umum yang sesuai dengan standar operasional.Terkadang auditor internal dalam menjalankan tugas dan fungsinya kurang menerapkan pengendalian perilaku.

Seorang auditor dalam mengembangkan pengendalian perilakunya tidak mampu melakukan tindakan pencegahan, pendeteksian, koreksi, dan kompensatif terhadap permasalahan yang dihadapinya, sehingga pengendalian perilaku yang dimiliki auditor sering dipertanyakan oleh pubik dalam rangka mempengaruhi kinerja manajerial organisasi.Mukhtar (2012:65-66) melakukan penelitian tentang analisis sistem pengendalian manajemen terhadap kinerja manajerial pada PDAM Kabupaten Gowa dengan mengambil sampel penelitian pada karyawan(i) yang terlibat dalam penyusunan program dan anggaran pada PDAM Kabupaten Gowa dengan menggunakan metode penelitian berdasarkan data kualitatif dan kuantitatif. Hasil penelitiannya menemukan bahwa pengalaman, otonomi, pengendalian perilaku, dan pengendalian personal berpengaruh positif dan signifikan terhadap kinerja manajerial. Dengan adanya penelitian tersebut maka dilakukan penelitian yang serupa dengan tempat yang berbeda 
yaitu pada PT. Bank Sulselbar Cabang Syariah Makassar. Dengan tujuan untuk mengetahui apakah dengan melakukan penelitian dengan variable yang sama, tapi dengan tempat penelitian yang berbeda akan memperoleh hasil yang berbeda terhadap kinerja auditor internal.

\section{LANDASAN TEORI}

\section{a. Pengertian Akuntansi Keperilakuan}

Akuntansi keperilakuan merupakan bagian dari disiplin ilmu akuntansi yang mengkaji hubungan antara perilaku manusia dan sistem akuntansi, serta dimensi keperilakuan dari organisasi dimana manusia dan sistem akuntansi itu berada dan diakui keberadaannya (Suartana,2010). Akuntansi keperilakuan menekankan pada pertimbangan dan pengambilan keputusan akuntan dan auditor, pengaruh dari fungsi akuntansi (misalnya partisipasi penganggaran, keketatan anggaran, dan karakter sistem informasi) dan fungsi auditing terhadap perilaku, misalnya pertimbangan (judgment) dan pengambilan keputusan auditor dan kualitas pertimbangan dan keputusan auditor, dan pengaruh dari keluaran dari fungsi-fungsi akuntansi berupa laporan keuangan terhadap pertimbangan pemakai dan pengambilan keputusan (menurut Bamber dalam Suartana, 2010:2).

Istilah sistem informasi akuntansi yang dimaksud disini dalam artian yang luas yang meliputi seluruh desain alat pengendalian manajemen diantaranya pengendalian, sistem penganggaran, desain akuntansi pertanggungjawaban, desain organisasi seperti desentralisasi atau sentralisasi, desain kolektibilitas biaya, penilaian kinerja, serta laporan keuangan.

Secara terperinci ruang lingkup akuntansi keperilakuan (Suartana, 2010) meliputi: 1.Mempelajari pengaruh antara perilaku manusia terhadap penggunaan sistem informasi akuntansi yang diterapkan dalam perusahaan dan organisasi, yang berarti bagimana sikap dan gaya kepemimpinan manajemen memengruhu sifat pengendalian akuntansi dan desain organisasi; apakah desain sistem pengendalian akuntansi diterapkan secara universal atau tidak.2.Mempelajari pengaruh sistem informasi akuntansi terhadap perilaku manusia, yang berarti bagaimana sistem akuntansi memengaruhi kinerja, motivasi, produktivitas, pengambilan keputusan, kepuasan kerja dan kerja sama.3.Metode untuk menjelaskan dan memprediksi perilaku manusia dan strategi untuk mengubahnya, yang berarti bagaimana sistem akuntansi dapat dipergunakan untuk memengaruhi perilaku, dan bagaimana mengatasi resistensi yang terjadi dalam perubahan sistem.

\section{b. Pengertian Audit Internal}

Pada tahun 1998 IIA membentuk kelompok kerja yang merumuskan pedoman (Guidance Task Force-GTF) yang bertugas mempertimbangkan perubahan-perubahan yang dilakukan pada standar dan pedoman lainnya. Salah satu hal penting GTF yaitu melakukan pengembangan terhadap suatu definisi baru untuk audit internal yang mampu menangkap esensi modern dari profesi tersebut dengan jelas dan ringkas. Pada musim semi tahun 1999 GTF menyerahkan definisi berikut ini untuk ditanggapi oleh para anggota The Institute Of Internal Auditors (IIA, 2010) sebagai berikut:

"audit internal adalah sebuah aktivitas konsultasi dan keyakina obyektif yang dikelola secara independen di dalam organisasi dan diarahkan oleh filosofi penambahan nilai untuk meningkatkan operasional perusahaan. Audit tersebut membantu organisasi dalam mencapai tujuannya dengan menerapkan pendekatan yang sistematis dan berdisiplin untuk mengevaluasi dan meningkatkan efektivitas proses pengelolaan resiko, kecukupan kontrol, dan pengelolaan organisasi”.

Audit internal merupakan profesi yang dinamis dan terus berkembang yang mengantisipasi perubahan dalam lingkungan operasinya dan beradaptasi terhadap perubahan dalam struktur organisasi, proses, dan teknologi. Profesionalisme dan komitmen yang tinggi 
Nurfaidah. Pengendalian Perilaku, dan Pengendalian Individual ...

difasilitasi dengan bekerja dalam kerangka praktik professional yang dikembangkan oleh Institute of Internal Auditors (Sawyer,2000:9).

Audit internal merupakan suatu aktivitas penilaian independen yang dibentuk dalam suatu organisasi yang melaksanakan kegiatannya bagi organisasi. Tujuan dari audit internal adalah untuk membantu anggota organisasi dalam pelaksanaan yang efektif dari tanggung jawab mereka dengan memberikan analisis, penilaian, saran-saran, rekomendasi, dan komentar yang terkait dengan kegiatan perusahaan yang diperiksa. Dilakukannya kegiatan audit internal juga bertujuan untuk membantu organisasi menerapkan kontrol yang efektif dengan mengevaluasi efektivitas dan efesiensi serta mendorong perbaikan yang terus menerus (sawyer, 2000:55).

Menurut Agoes dalam Priantinah (2012) dalam mencapai tujuannya, maka ruang lingkup yang harus dilakukan auditor internal meliputi:1.Menelaah dan menilai kebaikan, memadai tidaknya dan penerapan dari sistem pengendalian manajemen, pengendalian internal dan pengendalian operasional lainnya serta mengembangkan pengendalian yang efektif, efisien dan ekonomis.2.Memastikan ketaatan terhadap kebijakan, rencana, dan prosedur-prosedur yang telah ditetapkan oleh manajemen.3.Menelaah dan memastikan seberapa jauh harta perusahaan dipertanggungjawabkan dan dilindungi dari kemungkinan terjadinya segala bentuk penyelewengan seperti pencurian, kecurangan, dan penyalahgunaan.4.Memastikan bahwa pengelolaan data yang dikembangkan dalam organisasi/perusahaan dapat dipercaya.5.Menilai mutu pekerjaan setiap bagian dalam melaksanakan tugas yang diberikan oleh pihak manajemen dalam suatu organisasi/perusahaan.6.Menyarankan perbaikan-perbaikan operasional dalam rangka meningkatkan efisiensi dan efektivitas.

\section{c. Standar Profesional Audit Internal}

\section{1) Standar Atribut}

Priantinah (2011:17) Standar atribut adalah standar yang berkaitan dengan karakteristik organisasi dan pihak-pihak yang melakukan kegiatan audit internal. a. Tujuan, kewenangan, dan tanggung jawab harus dinyatakan secara formal, konsisten, serta disetujui pimpinan dan dewan pengawas organisasi. b. Independen dan objektif harus dimiliki auditor internal dalam melaksanakan tugasnya. c. Keahlian dan kecermatan professional harus dimiliki dalam melaksanakan penugasan, seperti pengetahuan, keterampilan, dan kompetensi dalam menjalankan tanggung jawab. d. Program quality assurance fungsi audit internal harus dikembangkan dan dipelihara dengan terus memonitor efktivitasnya.

\section{2) Standar Kinerja}

Menurut Priantinah (2011:18) Standar kinerja yaitu standar yang menjelaskan sifat dari kegiatan audit internal dan sebagai kriteria evaluasi kinerja.Pengelolaan fungsi audit internal dilakukan secara efektif dan efisien agar memberi nilai tambah bagi organisasi, dengan melakukan perencanaan, komunikasi dan persetujuan, pengelolaan sumber daya, penetapan kebijakan dan prosedur, koordinasi yang memadai dan menyampaikan laporan berkala pada pimpinan dan dewan pengawas.Lingkup penugasan Fungsi audit internal melakukan evaluasi dan memberikan kontribusi terhadap peningkatan proses pengelolaan risiko, pengendalian dan governance, dengan menggunakan pendekatan yang sistematis, teratur dan menyeluruh.Perencanaan penugasan Auditor internal harus mengembangkan dan mendokumentasikan rencana untuk setiap penugasan yang mencakup ruang lingkup, sasaran, waktu dan alokasi sumber daya. Disini auditor internal harus melakukan pertimbangan perencanaan, menentukan sasaran penugasan, menetapkan ruang lingkup penugasan, menentukan sumber daya dan menyusun program kerja yang menetapkan prosedur untuk mengidentifikasi, menganalisis, mengevaluasi, dan mendokumentasikan informasi selama penugasan.d.Pelaksanaan penugasan Auditor internal harus mengidentifikasi informasi yang 
handal dan relavan, mendasarkan kesimpulan dan hasil penugasan pada analisis dan evaluasi yang tepat, mendokumentasikan informasi yang relavan, dan supervisi penugasan dengan tepat untuk memastikan tercapainya sasaran, terjaminnya kualitas serta meningkatnya kemampuan staf.Komunikasi hasil penugasan.

Auditor internal harus mengkomunikasikan hasil penugasan sacara tepat waktu yang memenuhi kriteria komunikasi yang tepat; kualitas komunikasi yang akurat, objektif, jelas, ringkas, konstruktif, lengkap dan tepat waktu; pengungkapan atas ketidakpatuhan terhadap standar yang dapat mempengaruhi penugasan tertentu dan menyampaikan hasil penugasan pada pihak yang berhak.Pemantauan tindak lanjut.Menyusun dan penjaga sistem untuk memantau tindak lanjut hasil penugasan serta menyusun prosedur tindak lanjut untuk memantau dan memastikan pelaksanaan tindak lanjut secara efektif oleh manajemen.Resolusi penerimaan risiko oleh manajemen.Mendiskusikan masalah terkait risiko risidual yang tidak dapat diterma organisasi, jika tidak menghasilkan keputusan penanggung jawab fungsi auditor internal dan manajemen senior harus melapor pada pimpinan dan dewan pengawas organisasi untuk mendapat resolusi.

\section{METODE PENELITIAN}

Metode penelitian yang digunakan dalam penelitian ini yaitu metode penelitian kuantitatif, dengan pendekatan eksplanatori. Alasan utama pemilihan jenis penelitian eksplanatori ini untuk menguji hipotesis yang diajukan agar dapat menjelaskan pengaruh pengaruh secara parsial pengendalian perilaku terhadap kinerja auditor internal pada PT. Bank Sulselbar Cabang Syariah Makassar.

Teknik analisis data yang digunakan dalam penelitian ini adalah analisis regresi linier berganda. Model persamaannya adalah sebagai berikut:

Keterangan :

$$
Y=\alpha+\beta_{1} X_{1}+\beta_{2} X_{2}+e
$$

$\mathrm{Y}=$ Kinerja Auditor Internal

$\mathrm{X}_{1}=$ Pengendalian Perilaku

$\mathrm{X}_{2}=$ Pengendalian Individual

$\beta=$ koefisien regresi

$\alpha=$ Konstanta

$\mathrm{e}=$ eror term

\section{HASIL DAN PEMBAHASAN}

Analisis regresi berganda digunakan untuk mengetahui arah hubungan antara variabel independen dan variabel dependen. Persamaan regresi dapat dilihat dari tabel hasil uji coefisient berdasarakan output spss. Berikut adalah tabel ringkasan analisis linear berganda:

Tabel 1: Hasil Analisis Regresi

\begin{tabular}{|c|c|c|c|c|c|c|}
\hline \multirow[b]{2}{*}{ Model } & & \multicolumn{2}{|c|}{$\begin{array}{c}\text { Unstandardized } \\
\text { Coefficients }\end{array}$} & \multirow{2}{*}{$\begin{array}{c}\text { Standardized } \\
\text { Coefficients } \\
\text { Beta }\end{array}$} & \multirow[b]{2}{*}{$\mathrm{t}$} & \multirow[b]{2}{*}{ Sig. } \\
\hline & & B & Std. Error & & & \\
\hline \multirow[t]{3}{*}{1} & (Constant) & 2.218 & .817 & & 2.715 & .011 \\
\hline & Pengendalian Perilaku & .241 & .085 & .432 & 2.815 & .009 \\
\hline & Pengendalian Individual & .387 & .178 & .334 & 2.178 & .038 \\
\hline
\end{tabular}

Sumber : Data yang diolah, 2016

Berdasarkan Tabel 1, maka persamaan regresi yang terbentuk pada uji regresi ini adalah: 
Nurfaidah. Pengendalian Perilaku, dan Pengendalian Individual ...

$$
\mathrm{Y}=2.218+0.241 \mathrm{X}_{1}+0.387 \mathrm{X}_{2}+\mathrm{e}
$$

Hasil pengujian yang diperoleh diatas adalah sebagai berikut : a.Nilai konstanta $(\alpha)$ yang diperoleh sebesar 2.218 artinya jika variabel Pengendalian Perilaku, dan Pengendalian Individual bernilai 0 maka besarnya tingkat Kinerja Auditor Internal yang terjadi adalah sebesar 2.218.b.Koefisien regresi $\mathrm{X}_{1}=0.241$ artinya jika Pengendalian Perilaku naik sebanyak 1 satuan, maka Kinerja Auditor Internal meningkat sebesar 0.241.c.Koefisien regresi $\mathrm{X}_{2}=0.387$ artinya jika Pengendalian Individual naik sebanyak 1 satuan maka Kinerja Auditor Internal meningkat sebesar 0.387 .

Pengendalian perilaku secara parsial berpengaruh terhadap kinerja auditor internal pada PT. Bank Sulselbar Cabang Syariah Makassar.Pernyataan hipotesis pertama bahwa pengendalian perilaku secara parsial berpengaruh terhadap kinerja auditor internal diterima. Hal ini dapat ditunjukkan dengan nilai signifikansi ( $P$ V alue) 0.009 yang lebih kecil dari 0.05 serta nilai koefisien regresi sebesar 0.241. dapat disimpulkan bahwa perilaku secara parsial berpengaruh signifikan terhadap kinerja auditor internal. Pengendalian individual secara parsial berpengaruh terhadap kinerja auditor internal pada PT. Bank Sulselbar Cabang Syariah Makassar.Pernyataan hipotesis kedua bahwa pengendalian individual secara parsial berpengaruh terhadap kinerja auditor internal diterima. Hal ini dapat ditunjukkan dengan nilai signifikansi ( $P$ V alue) 0.038 yang lebih kecil dari 0.05 serta nilai koefisien regresi sebesar 0.387 dapat disimpulkan bahwa individual secara parsial berpengaruh signifikan terhadap kinerja auditor internal.

Berdasarkan hasil uji hipotesis, yaitu pengendalian perilaku dan pengendalian individual yang di uji secara parsial (Uji-t) terhadap kinerja auditor internal memperoleh hasil yang signifikan untuk seluruh variabel yang dijadikan alat ukur sehingga hipotesis pertama $\left(\mathrm{H}_{1}\right)$ dan hipotesis kedua $\left(\mathrm{H}_{2}\right)$ terbukti. Hal ini mengindikasikan bahwa pengendalian perilaku, dan pengendalian individual dapat berpengaruh secara parsial untuk meningkatkan kinerja auditor internal. Jika diuji secara parsial maka hasil penelitian ini sejalan dengan penelitian Mukhtar (2012) dan Primantoro (2010) yang menyatakan bahwa pengendalian perilakudan pengendalian individual sebagai moderator dalam meningkatkan prestasi kerja.

Pengendalian perilaku, dan pengendalian individual secara simultan berpengaruh terhadap kinerja auditor internal pada PT. Bank Sulselbar Cabang Syariah Makassar. Pernyataan hipotesis ketiga bahwa pengendalian perilaku, dan pengendalian individual secara secara simultan atau bersama-sama berpengaruh terhadap kinerja auditor internal terbukti. Berdasarkan hasil uji F diperoleh nilai signifikansi (P V alue) sebesar 0,004 ${ }^{\mathrm{b}}$ lebih kecil dari 0,05. Sehingga terbukti bahwa secara simultan pengendalian perilaku, dan pengendalian individual berpengaruh positif dan signifikan terhadap kinerja auditor internal pada PT. Bank Sulselbar Cabang Syariah Makassar. Dapat diambil kesimpulan bahwa jika pengendalian perilaku, dan pengendalian individual dijalankan secara bersama-sama maka akan lebih membantu dalam meningkatkan dan memotivasi kinerjaa uditor internal. Auditor yang berpengalaman mempunyai pemahaman yang lebih baik. Mereka juga lebih mampu member penjelasan yang masuk akal atas kesalahan-kesalahan dalam laporan keuangan dan dapat mengelompokkan kesalahan berdasarkan pada tujuan audit dan struktur dari system akuntansi. Auditor pada peringkat yang lebih rendah memiliki audit experience dan pengawasan yang rendah juga.

Manajer dan partners tidak hanya memiliki banyak audit experience, tetapi juga dapat diharapkan memiliki kompetisi teknis dan menunjukkan kualitas kepemimpinan untuk meraih posisi pada masing- masing perusahaan. Walaupun auditor mungkindapat bekerja dengan apa yang diharapkan pada tiap tingkat, ada juga individu ditingkat bawah yang tidak bekerja sesuai dengan apa yang diharapkan dan mereka dapat meninggalkan perusahaan baik secara sengaja ataupun tidak sengaja. Adapula pengendalian perilaku dan pengendalian individual yang menjadi faktor dalam peningkatan kinerja auditor. 
Tujuan pengendalian perilaku adalah untuk menjamin hasil yang ingin dicapai, meliputi aktivitas pengawasan, monitoring, dan aktivitas yang sedang berjalan. Aktivitas tersebut berperilaku sesuai dengan cara yang dikehendaki sehingga dalam suatu organisasi pengendalian perilaku akan memengaruhi terhadap kinerja organisasional. Apabila suatu tujuan tertentu tercapai maka dapat dikatakan bahwa kegiatan tersebut efektif dan efisien. Konsep pengendalian individual merupakan konsep pengembangan perilaku yang perlu dikontrol dalam melakukan audit yang menyalahi perilaku akuntansi.

Pengendalian individual dibangun berdasarkan kekuatan potensi individual menjalani dinamika kerja untuk mewujudkan hasil kerja optimal.Inti dari sebuah aktivitas pengendalian individual dalam kegiatan perilaku akuntansi adalah mengukur kemampuan seseorang berdasarkan kompetensi,motivasi, disiplin kerja, dan tanggungjawab atas pengalaman, otonomi dan pengendalian perilaku yang dimilikinya. Dari kedua faktor tersebut, yaitu pengendalian perilaku, dan pengendalian individual maka akan memperoleh tingkat kinerja yang baik bagi seoranga uditor.

Robbins (2010) menjelaskan bahwa "kinerja merupakan hasil evaluasi terhadap pekerjaan yang dilakukan individu dibandingkan dengan criteria yang telah ditetapkan bersama, pengertian kinerja sebagai hasil kerja secara kualitas dan kuantitas yang dicapai individu dalam melaksanakan tugasnya sesuai dengan tanggungjawab yang diberikan kapadanya. Jika diuji secara simultan, maka hasil penelitian ini sejalan dengan penelitian Prasetya (2011) dan Mukhtar (2012) dimana seluruh penelitian tersebut menemukan bahwa pengendalian perilaku, dan pengendalian individual berpengaruh secara positif dan signifikan terhadap prestasi kerja.

\section{PENUTUP}

Berdasarkan dari uraian di atas, maka ada beberapa yang dapat disimpulkan yaitu pengaruh pengendalian perilaku, dan pengendalian individual terhadap kinerja auditor internal pada PT. Bank Sulselbar Cabang Syariah Makassar, dengan bantuan analisisi regresi linear berganda dan pengujuian hipotesis yaitu uji parsial (uji t) dan uji simultan (uji f) maka dapat ditarik kesimpulan sebagai berikut: Pengendalian perilaku secara parsial berpengaruh signifikan terhadap kinerja auditor internal, hal ini dapat dilihat dari nilai signifikansi ( $P$ Value $) 0.009<$ 0.05. Pengendalian individual secara parsial berpengaruh terhadap kinerja auditor internal dengan taraf signifikansi ( $P$ V alue) 0.038 yang lebih kecil dari 0.05 .

Hasil pengujian secara simultan, menunjukkan bahwa pengendalian perilaku, dan pengendalian individualberpengaruh secara bersama-sama terhadap peningkatan kinerja auditor internal pada auditor. Hal ini ditinjau dari hasil uji $\mathrm{F}$ diperoleh $\mathrm{F}_{\text {hitung }}$ sebesar 6.886 dengan taraf signifikansi (tingkat probabilitas) sebesar $0,004^{\mathrm{b}}<0,05$. Dan Nilai koefisien determinasi $\left(R^{2}\right)$ yang dihasilkan adalah 0,322 . Hal ini berarti sebesar 32.2 persen perubahan variabel dependen (kinerja auditor internal) dapat dijelaskan oleh perubahan variabel independen (pengendalian perilaku dan pengendalian individual) secara bersama-sama, sedangkan selebihnya sebesar $67.8 \%(100 \%$ - 32.2\%) ditentukan oleh faktor lain yang tidak diketahui dan tidak termasuk dalam analisa regresi ini.

\section{DAFTAR PUSTAKA}

Awaluddin, Murtiadi. "Pengarub Independensi dan Kompetensi Auditor Terhadap Kepuasan Kerja dan Kinerja Auditor Inspektorat Kota Makassar." Jurnal Assets 3 (2013).

Awaluddin, Murtiadi. 2013. Effect of Auditor Independence and Competence on Job Satisfaction and Performance Inspection Auditor Makassar. Journal of Managerial Vo. 1, No. December 1, 2013: 13-23. 
Nurfaidah. Pengendalian Perilaku, dan Pengendalian Individual ...

Mukhtar, Ludin. 2012. Analisis Sistem Pengendalian Manajemen terhadap Kinerja Manajerial pada PDAM Kabupaten Gowa. Tesis. Makassar: Program Pascasarjana Universitas Hasanuddin.

Prasetya, Bayu Adi. 2011. Pengarub Tanggung Jawab, Pengalaman, Otonomi terhadap Prestasi Kerja Auditor di Kantor Akuntan Publik Kota Semarang. Skripsi. Semarang: Program Sarjana Fakultas Ekonomi, Universitas Diponegoro.

Priantinah, Denies dan Megasari, Chitra. 2012. Persepsi Karyawan tentang Peran Auditor Internal sebagai Pengawas, Konsultasi, dan katalisator dalam Pencapaian Tujuan Perusahaan (Studi Kasus di Hotel Inna Garuda Yogyakarta). Jurnal Nominal Volume 1 tahun 2012.

Primantoro, Teguh. 2010. Pengarub Pengendalian Akuntansi, Pengendalian Perilaku dan Pengendalian Personal terhadap Kinerja Manajerial pada PT Kertas Rajasa Raya Sidoarjo. Artikel Akuntansi. Jawa Timur: Fakultas Ekonomi, Universitas Pembangunan Nasional "Veteran".

Robbins, Stephen P.Robbins, Stephen P. 2003. Perilaku Organisasi. Terjemahkan oleh Benyamin Molan. 2006. Jakarta : Indeks Gramedia.

Sawyer, Lawrence B., Mortimer A. Dittenhoper, dan James H. Scheiner. 2000. Sanyer' Internal Auditing. Edisi 5. Diterjemahkan oleh Desi Adhariani. Jakarta: Penerbit Salemba Empat.

Suartana, I Wayan. 2010. Akuntansi Keperilakuan Teori dan Implementasi. Yogyakarta: ANDI.

Sugiyono. 2010. Statistika Untuk Penelitian. Bandung: CV. Alfabeta

Sunjoyo, Dkk., 2013. Analisis Regresi dan Uji Hipotesis. Yogyakarta: CAPS.

The Institute of Internal Audit (IIA). 2012. International Standards for The Professional Practice of Internal Auditing (Standards). United States of America. https://na.theiia.org. Diakses pada tanggal 12 februari 2014.

The Institute of Internal Audit (IIA). 2010. Foundation of an Internal Audit Activity-Inst of Internal Auditors.www.libgen.org. Diakses pada 12 November 2013. 